\title{
Multilocus sequence analysis of root nodule isolates from Lotus arabicus (Senegal), Lotus creticus, Argyrolobium uniflorum and Medicago sativa (Tunisia) and description of Ensifer numidicus sp. nov. and Ensifer garamanticus sp. nov.
}

Correspondence
P. de Lajudie
Philippe.Lajudie@ird.fr
C. Merabet, ${ }^{1,2}$ M. Martens, ${ }^{3}$ M. Mahdhi, ${ }^{2,4}$ F. Zakhia, ${ }^{2}+$ A. Sy, ${ }^{5}$ C. Le Roux, ${ }^{2}$ O. Domergue, ${ }^{2}$ R. Coopman, ${ }^{3}$ A. Bekki, ${ }^{1}$ M. Mars, ${ }^{4}$ A. Willems ${ }^{3}$ and P. de Lajudie ${ }^{2}$

\author{
${ }^{1}$ Laboratoire de Rhizobiologie, Université d'Oran, Es-Senia, Algeria \\ ${ }^{2}$ IRD, UMR 113 Symbioses Tropicales et Méditerranéennes F-34398 Montpellier, France \\ ${ }^{3}$ Laboratorium voor Microbiologie (WE10), Universiteit Gent, Belgium \\ ${ }^{4}$ Faculté des Sciences, Gabès, Tunisia \\ ${ }^{5}$ IRD-UCAD-ISRA, Laboratoire Commun de Microbiologie, Dakar, Senegal, West Africa
}

\section{INTRODUCTION}

Over the past three decades, bacterial taxonomy has been based on a polyphasic approach including both phenotypic and genotypic data with $16 \mathrm{~S}$ rRNA gene sequence analysis and DNA-DNA hybridization data being considered as the cornerstones of genotypic characterization for descriptions of novel species (Vandamme et al., 1996; Stackebrandt et al., 2002; Coenye et al., 2005). However, many authors have reported drawbacks with these methods (Ueda et al., 1999; Stackebrandt et al., 2002; Schouls et al., 2003; Stackebrandt,

tPresent address: Département des Sciences Naturelles, Faculté des Sciences, Université Libanaise II Fanar, Lebanon.

Abbreviations: ARDRA, amplified rDNA restriction analysis; ML, maximum-likelihood; MLSA, multilocus sequence analysis; MP, maximum-parsimony; NJ, neighbour-joining.

The GenBank/EMBL/DDBJ accession numbers of the new sequences reported in this paper are provided in Table 1. The GenBank accession numbers for the partial NodA gene sequences for Ensifer adhaerens strain ORS 529. Ensifer garamanticus strain ORS $1400^{\top}$, Ensifer numidicus strain ORS 1444 and E. garamanticus strain STM 354 are FJ919754-FJ919757, respectively.

Supplementary tables listing the primers used for the amplification of the five housekeeping genes ( $\operatorname{tat} D, \operatorname{rec} A, \operatorname{glt} A, \operatorname{thr} C$ and $g \ln A)$ and the nod $A$ gene and the results of the API 100 galleries are available as supplementary data with the online version of this paper. Additional supplementary figures showing the phylogenetic trees for the five housekeeping genes and a concatenated tree comparing the Tunisian and Senegalese strains with reference strains of the genus Ensifer are also available. 
2003; van Berkum et al., 2003; Eardly et al., 2005). The ad hoc Committee for the Re-evaluation of the Species Definition in Bacteriology (Stackebrandt et al., 2002; Gevers et al., 2005) suggested the sequence analysis of a set of protein-encoding genes as alternative phylogenetic markers, or multilocus sequence analysis (MLSA). Several recent studies have confirmed that sequences from housekeeping genes can be used for identification at the species level (Wertz et al., 2003; Zeigler, 2003), for evolutionary population genetics and in taxonomy (Stepkowski et al., 2003; Vinuesa et al., 2005a,b; Bailly et al., 2006). The analysis of a small number of carefully selected gene sequences may equal or even surpass the precision of DNA-DNA hybridization for the quantification of genome relatedness and this approach thus has the potential to replace cumbersome DNA-DNA hybridizations (Zeigler, 2003, Martens et al., 2008). Mantelin et al. (2006) included MLSA in the description of four novel species of the genus Phyllobacterium and Vinuesa et al. (2005c) described novel species of the genus Bradyrhizobium using phylogenetic analysis of three housekeeping genes, atpD, glnII and recA, combined with other classical genotypic and phenotypic analyses. 'Ensifer mexicanus' and 'Sinorhizobium chiapanecum' were described using phenotypic analysis, phylogenies of the recA, gyrA, nolR, rpoB, rrs and symbiotic genes and confidence intervals of sequence similarity to estimate both inter- and intraspecies variation; all were in correlation with DNA-DNA hybridization data (Lloret et al., 2007; RincónRosales et al., 2009). In addition, MLSA has been applied in diversity studies of the genera Enterococcus, Aeromonas and Ensifer (Sinorhizobium) (Naser et al., 2005; Soler et al., 2004; Bailly et al., 2006) and it has been reported as being a highly reproducible and economical method for rapid and reliable species identification.

The genera Sinorhizobium and Ensifer were recently recognized as forming a single phylogenetic clade (Balkwill, 2005; Willems et al., 2003) and are now united and all species of the genus Sinorhizobium have been transferred to the genus Ensifer, in line with rule 38 of the Bacteriological Code (Young, 2003; Judicial Commission, 2008). The genus Ensifer currently includes eleven species (Wang et al., 2002; Wei et al., 2002; Young, 2003; Toledo et al. 2003). Two further species, 'Ensifer mexicanus' and 'Sinorhizobium chiapanecum', have been described but the names have not yet been validly published (Lloret et al. 2007; Rincón-Rosales et al., 2009). Martens et al. $(2007,2008)$ recently demonstrated that the discriminative power of MLSA for species identification and delineation is higher than 16S rRNA gene sequence analysis and DNA-DNA hybridization within the genus Ensifer.

In this study, MLSA was performed to complete the characterization of nine root nodule strains isolated from several legumes in Tunisia (Argyrolobium uniflorum, Lotus creticus, Medicago sativa) and Senegal (Lotus arabicus). Argyrolobium uniflorum (Tribe Genisteae, Family Fabaceae) is an indigenous herb legume of the Mediterranean basin and is a pastoral and forage legume that is widely distributed in arid and semi-arid regions of Tunisia. This plant plays an important role in the maintenance of soil fertility, soil coverage and dune stability (Ferchichi, 1996). Lotus arabicus L. (tribe Loteae, family Fabaceae), syn. Lotus mossamedensis Welw. ex Baker, is a spontaneous annual herb legume of coastal dunes in Senegal. Medicago sativa is the most widely cultivated species of lucerne in the world and its symbiotic rhizobial strains have been extensively studied. Six of the isolates have previously been analysed by amplified rDNA restriction analysis (ARDRA) using seven enzymes, total cell protein SDS-PAGE analysis and 16S rRNA gene sequencing (Zakhia et al., 2004) and results suggested their separate positions in the genus Ensifer (pro synon. Sinorhizobium). According to the conclusions of Martens et al. (2007, 2008), the strains were subjected to MLSA using five housekeeping genes, the most discriminative for taxonomic purposes of the ten housekeeping genes evaluated in the genus Ensifer. Genes were analysed individually and as a concatenation using only the congruent genes estimated by the incongruence-length difference (ILD) test (Farris et al., 1995). Trees were constructed using three algorithmic methods for comparison. The characterization was completed by auxanographic tests, DNA-DNA hybridizations, host specificity investigations and sequence analysis of the symbiotic nodA gene for biovar description.

\section{METHODS}

Bacterial strains and culture media. The strains investigated are listed in Table 1. All strains were grown on yeast-mannitol agar (YMA) (Zakhia et al., 2004) at $28{ }^{\circ} \mathrm{C}$. Isolates were stored at $-80{ }^{\circ} \mathrm{C}$ in $50 \%(\mathrm{v} / \mathrm{v})$ glycerol.

Host specificity. The isolates were tested for nodulation on their original host plant. The seeds from Medicago sativa and Lotus arabicus were sterilized in $3 \%(\mathrm{w} / \mathrm{v})$ calcium hypochlorite and scarified by immersion in $96 \%(\mathrm{v} / \mathrm{v})$ sulphuric acid for $20 \mathrm{~min}$. The seeds were then washed five times with sterile water and placed in $1 \%(\mathrm{w} / \mathrm{v})$ agar-water at $24-25{ }^{\circ} \mathrm{C}$ for germination. After 3-4 days, the seedlings were transferred to agar slant tubes (Bertrand, 1997) for root nodulation trials ( 5 plants per strain). Plants were grown under continuous light $\left(20 \mathrm{~W} \mathrm{~m}^{-2}\right)$ at $24{ }^{\circ} \mathrm{C}$ and inoculated with $1 \mathrm{ml}$ exponential growth phase YM bacterial suspension. Roots were observed for nodule formation during the first 4 weeks after inoculation. The infectivity of strains isolated from Argyrolobium uniflorum has been previously reported by Zakhia (2004).

Genomic DNA isolation. Bacterial DNA was prepared as described by Zakhia et al. (2004) or alternatively by the alkaline lysis method (Baele et al., 2000).

DNA amplification. The $16 \mathrm{~S}$ rRNA gene, internal fragments of five housekeeping genes $(a t p D, \operatorname{rec} A, \operatorname{glt} A, \operatorname{thr} C$ and $\operatorname{gln} A)$ and the $\operatorname{nod} A$ gene were amplified using primers listed in Supplementary Table S1 (available in IJSEM Online). PCR amplification of the atpD, $\operatorname{rec} A$, $g l t A, \operatorname{th} r C$ and $g \ln A$ genes was performed as described by Martens et al. (2007) with the exception that the total volume of the reaction mixture was $25 \mu \mathrm{l}$. PCR amplification of the $16 \mathrm{~S}$ rRNA gene was performed according to Zakhia et al. (2004) and nodA gene amplification was conducted as described by Zakhia et al. (2006).

Gene sequencing and phylogenetic data analysis. The PCR products of the different genes were purified and sequenced as previously 
Table 1. GenBank accession numbers for new sequence data

NA, Not amplified.

\begin{tabular}{|c|c|c|c|c|c|c|c|}
\hline Strain & SSU & $\operatorname{rec} A$ & $g \ln A$ & $\operatorname{atpD}$ & thrC & gltA & Source \\
\hline \multicolumn{8}{|l|}{ E. numidicus sp. nov. } \\
\hline $\begin{array}{l}\text { ORS } 1444(=\mathrm{LMG} \\
\left.24691=\mathrm{CIP} 109850^{\mathrm{T}}\right)\end{array}$ & AY500253 & AM946578 & AM946562 & AM946549 & AM946586 & AM946596 & $\begin{array}{l}\text { Argyrolobium uniflorum, } \\
\text { Tunisia, Zakhia et al. (2004) }\end{array}$ \\
\hline $\begin{array}{l}\text { ORS } 1410(=\mathrm{LMG} \\
24736=\mathrm{CIP} 109858)\end{array}$ & AM946566 & AM946577 & AM946561 & AM946550 & NA & AM946595 & $\begin{array}{l}\text { Lotus creticus, } \\
\text { Tunisia, Zakhia et al. (2004) }\end{array}$ \\
\hline $\begin{array}{l}\text { ORS } 1407^{\mathrm{T}}(=\mathrm{LMG} \\
\left.24690^{\mathrm{T}}=\text { CIP } 109850^{\mathrm{T}}\right)\end{array}$ & AY500254 & AM946576 & AM946560 & AM946551 & AM946585 & AM946594 & $\begin{array}{l}\text { Argyrolobium uniflorum, } \\
\text { Tunisia, Zakhia et al. (2004) }\end{array}$ \\
\hline \multicolumn{8}{|l|}{ E. garamanticus sp. nov. } \\
\hline $\begin{array}{l}\text { ORS } 1400^{\mathrm{T}}(=\mathrm{LMG} \\
\left.24692^{\mathrm{T}}=\mathrm{CIP} 109916^{\mathrm{T}}\right)\end{array}$ & AY500255 & AM946573 & AM946557 & AM946546 & AM946582 & AM946591 & $\begin{array}{l}\text { Argyrolobium uniflorum, } \\
\text { Tunisia, Zakhia et al. (2004) }\end{array}$ \\
\hline $\begin{array}{l}\text { ORS } 1401(=\mathrm{LMG} \\
24693=\mathrm{CIP} 109848)\end{array}$ & AM946567 & AM946574 & AM946558 & AM946547 & AM946583 & AM946592 & $\begin{array}{l}\text { Argyrolobium uniflorum, } \\
\text { Tunisia, Zakhia et al. (2004) }\end{array}$ \\
\hline $\begin{array}{l}\text { STM } 354 \text { (=LMG } \\
24694=\text { CIP 109849) }\end{array}$ & AM946568 & AM946575 & AM946559 & AM946548 & AM946584 & AM946593 & $\begin{array}{l}\text { Medicago sativa, } \\
\text { Tunisia, Zakhia et al. (2004) }\end{array}$ \\
\hline \multicolumn{8}{|l|}{ E. adhaerens genomovar A } \\
\hline ORS 2154 & AM946569 & AM946579 & AM946565 & AM946553 & AM946587 & AM946598 & $\begin{array}{l}\text { Lotus arabicus, Senegal, } \\
\text { this study }\end{array}$ \\
\hline ORS 2133 & AM946570 & AM946580 & AM946563 & AM946554 & AM946588 & AM946597 & $\begin{array}{l}\text { Lotus arabicus, Senegal, } \\
\text { this study }\end{array}$ \\
\hline ORS 529 & AM946571 & AM946581 & AM946564 & AM946555 & AM946589 & AM946599 & $\begin{array}{l}\text { Lotus arabicus, Senegal, } \\
\text { this study }\end{array}$ \\
\hline
\end{tabular}

described (Martens et al., 2007) using the primers detailed in Supplementary Table S1 (available in IJSEM Online). Consensus sequences were constructed using the Autoassembler software (Applied Biosystems). Interstrain sequence similarity ( $\mathrm{S}$ ) values were determined applying pairwise sequence alignments using BioNumerics 4.6. software. The nucleotide sequences of partial $\operatorname{atp} D, \operatorname{rec} A, g l t A, g \ln A, t h r C$ and small subunit rRNA (SSU) were independently aligned using the CLUSTAL_X program, version 1.8 (Thompson et al., 1997). Neighbour-joining (NJ), maximum-parsimony (MP) and maximum-likelihood (ML) trees were constructed using PAUP version 4.0b10 (Swofford, 2002). Reference sequences of species of the genus Ensifer were included for comparison (GenBank accession nos are listed in Martens et al., 2008). NJ analyses (Saitou \& Nei, 1987) were performed using the Kimura 2 correction (Kimura, 1980) and 1000 bootstrap replications; MP analyses were performed using the heuristic search option. For ML analyses, the optimal models of nucleotide substitution were estimated using the program MODELTEST 3.7 (Posada \& Crandall, 1998), using Akaike's Information Criterion (AIC) (Posada \& Buckley, 2004). The MP trees were used as starting trees for the heuristic search procedure. Bootstrap analyses were performed using 1000 replications of heuristic searches for MP and 100 replications for ML. The ILD test (Farris et al., 1995), implemented in PAUP* and using 1250 replicates, was used to assess incongruence between datasets. A phylogenetic tree was constructed with the concatenated sequences of the congruent housekeeping genes.

DNA-DNA hybridization. DNA was prepared according to a slightly modified procedure of Marmur (1961) as described previously (Willems et al., 2001). Hybridizations were carried out using the microplate method in which unlabelled DNA, non-covalently bound to the microplate, was hybridized with biotinylated probe DNA (Ezaki et al., 1989; Goris et al., 1998; Willems et al., 2001). Hybridizations were performed at $45{ }^{\circ} \mathrm{C}$ in $2 \times$ SSC and $50 \%$ formamide.

Phenotypic tests. Microscopic observations, growth at various temperatures and $\mathrm{pH}$ values, and tolerance to $\mathrm{NaCl}$ were performed as previously described (de Lajudie et al., 1994; Mahdhi et al., 2008).
API 100 galleries (bioMérieux) were used to test the utilization of carbon sources (carbohydrates, amino acids, organic acids) for bacterial growth. Inoculants were obtained from $36 \mathrm{~h}$ YMA slant cultures. After inoculation, the galleries were incubated at $30{ }^{\circ} \mathrm{C}$ and the results were determined after 1,2, 4 and 7 days. The results of the auxanographic tests were scored as described previously (Kersters \& De Ley, 1984). Jaccard similarity coefficients were calculated and an UPGMA analysis was performed using BioNumerics 4.6.

\section{RESULTS}

\section{Nodulation tests}

All of the strains studied induced efficient nodulation on their hosts of isolation. This has already been reported by Zakhia (2004) for strains ORS $1400^{\mathrm{T}}$, ORS 1401, ORS $1407^{\mathrm{T}}$, ORS 1444 (Argyrolobium uniflorum) and for strain ORS 1410 (Medicago sativa). In this study, strains ORS 2154, ORS 2133 and ORS 529, isolated from Lotus arabicus, were tested and were effective on their plant of isolation.

\section{5 rRNA gene sequence analysis}

Nearly full-length $16 \mathrm{~S}$ rRNA gene sequences (1340 bp) were determined for strains ORS 1410, ORS 2133, ORS 529, ORS 2154, ORS 1401 and STM 354. The 16S rRNA gene phylogenetic trees constructed using three methods (ML, MP, NJ) resulted in the same groupings. Therefore, only the resulting ML tree is shown in Fig. 1. All isolates studied were placed unambiguously within the class Alphaproteobacteria and within the clade of the reference species of the genus Ensifer. The isolates were subdivided 


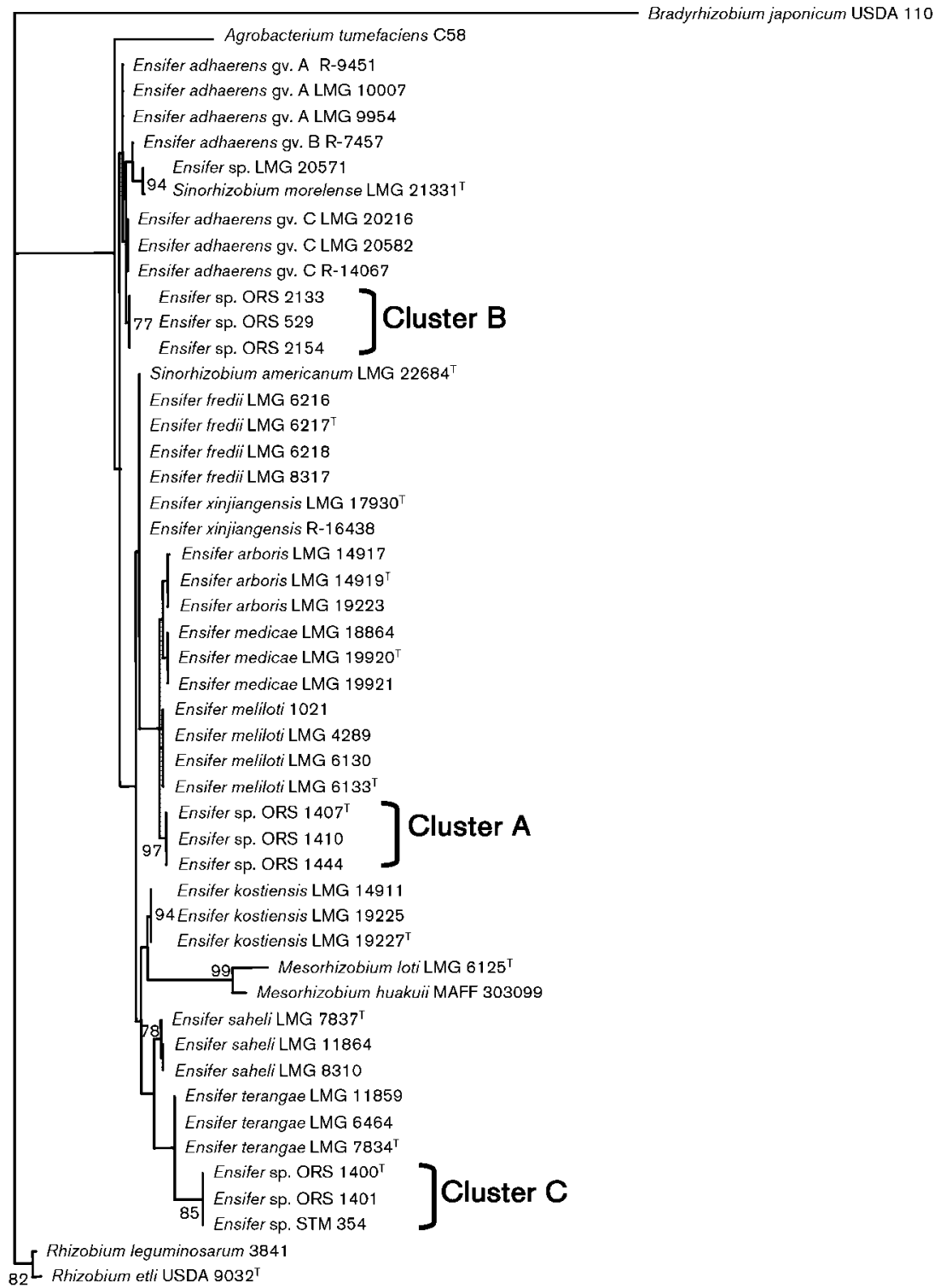

Fig. 1. Phylogenetic reconstruction based on individual analysis of the 16S rRNA gene. Analyses were conducted using the $\mathrm{ML}$ method. Bootstrap values $>75$ (using 100 replicates) are indicated at branching points. Bar, $0.1 \%$ estimated substitutions.

into three clusters (clusters A, B and C) supported by high bootstrap values and displaying high intra-cluster sequence similarity.

Cluster A (bootstrap value $97 \%$ ) included isolates ORS 1444, ORS 1410 and ORS 1407 and formed a homogeneous group (sequence similarity values $100 \%$ ) that was equally distant to Ensifer arboris, Ensifer medicae and Ensifer meliloti (99.7\% sequence similarity).

Cluster B strains (ORS 529, ORS 2154 and ORS 2133) also shared identical 16S rRNA gene sequences and formed a clade grouping together with the genomovars of Ensifer adhaerens ( $\geqslant 99.6-99.8 \%$ sequence similarity) and reference strains of Sinorhizobium morelense (99.0-99.2\% sequence similarity), although low bootstrap values were displayed for this group (35\%).
Strains ORS $1400^{\mathrm{T}}$, ORS 1401 and STM 354 formed a homogeneous group (Cluster C, 100\% interstrain gene sequence similarity values) supported by a bootstrap value of $85 \%$, and clustered in the vicinity of Ensifer terangae (48\% bootstrap value and $98.8 \%$ sequence similarity). The reference strain of 'E. mexicanus' LMG 23932, which was described recently (Lloret et al., 2007), was related to these taxa. It was not included in our analyses, but formed a distinct subclade, sharing sequence similarity values of $97.8-98.8 \%$ with clusters $\mathrm{A}, \mathrm{B}$ and $\mathrm{C}$ and $99.5 \%$ with strains of E. terangae.

\section{Sequence analysis of individual genes}

The five housekeeping gene fragments examined in this study had different lengths: $g \ln A$ (977 bp), gltA (681 bp), recA (550 bp), atpD (461 bp), thrC (636 bp). Within each group 
A, B and C, the three strains of each group had identical sequences for all genes tested (except for ORS 1410 of group A for which the $t h r C$ gene could not be amplified). Sequence analysis of the five individual housekeeping genes resulted in different tree topologies (see Supplementary Fig. S1. in IJSEM Online). However, the same three separate clusters A, $\mathrm{B}$ and $\mathrm{C}$ were revealed with high bootstrap support for all clusters in all gene analyses, including those of the $16 \mathrm{~S}$ rRNA genes. These clusters occupied different positions relative to the reference species depending on the gene considered.

In the atpD gene tree topology, Agrobacterium tumefaciens grouped with $S$. morelense, the three genomovars of E. adhaerens and all strains from cluster B (100\% bootstrap), although this cluster had low bootstrap support $(32 \%)$. A second cluster (bootstrap value $43 \%$ ) contained all other species of the genus Ensifer and clusters A and C (both clusters $100 \%$ bootstrap value).

In the case of the gltA gene, all strains of the genus Ensifer, together with clusters A, B and C, formed a single separate but poorly supported clade (bootstrap value $38 \%$ ). Within this clade, all strains from cluster $\mathrm{C}$ formed a significant subclade with E. terangae ( $100 \%$ bootstrap). Another wellsupported subgroup (bootstrap value $98 \%$ ) was formed by all strains from cluster B and E. adhaerens genomovar A.

In the $g \ln A$ gene analysis, all strains of the genus Ensifer (and clusters A, B and C) were grouped together with high bootstrap support $(75 \%)$ and the same two significant subclusters that appeared in the gltA gene tree topology were found (bootstrap values 100 and $95 \%$ for cluster C/E. terangae and cluster $\mathrm{B} /$ E. adhaerens genomovar $\mathrm{A}$, respectively).

In the thrC gene tree, all strains of the genus Ensifer together with clusters A, B and C, formed a single, separate but less supported clade (bootstrap value $48 \%$ ), in which the same two subclades were again distinguished (bootstrap values 100 and $98 \%$ for cluster $\mathrm{C} / E$. terangae and cluster $\mathrm{B} / E$. adhaerens genomovar $\mathrm{A}$, respectively). In the final single gene tree, the recA tree, all Ensifer strains and clusters $\mathrm{A}, \mathrm{B}$ and $\mathrm{C}$ again formed a separate, but poorly supported, clade (bootstrap value $27 \%$ ). A well-supported subgroup (bootstrap value $95 \%$ ) was formed by all strains from cluster B and E. adhaerens genomovar A.

Thus, cluster A formed a separate, well-supported group (bootstrap value $100 \%$ ) in all single gene phylogenies with identical sequences for the three strains $(100 \%)$. Cluster A was located at different positions when compared with the reference species of the genus Ensifer and no significant clusterings were apparent. The highest observed sequence similarities between cluster A strains and the reference species ranged between $86.9 \%$ with Ensifer saheli and Ensifer kostiensis for the $t h r C$ gene and $94.3 \%$ with reference strains Ensifer meliloti and Ensifer medicae for the atpD gene.

Cluster B grouped with E. adhaerens, more specifically E. adhaerens genomovar A, with high bootstrap values in all housekeeping gene analyses, except for the atpD gene. Sequence similarities with $E$. adhaerens genomovar A strains ranged between $96.4 \%$ for $\operatorname{thr} \mathrm{C}$ to $98.4 \%$ for the $r e c A$ gene. With both other genomovars, the range was lower at $90.5 \%(g l t A)$ to $95.3 \%(g \ln A)$.

Strains ORS $1400^{\mathrm{T}}$, ORS 1401 and STM 354 formed the monophyletic Cluster $\mathrm{C}$ in all gene phylogenies (bootstrap value ranging from 98 to $100 \%$; sequence similarity values $100 \%$ for all genes). This cluster displayed sequence similarities with its closest neighbour $E$. terangae in the range of $92.2 \%$ (for recA) to $96.4 \%$ (for gltA). Cluster $\mathrm{C}$ together with $E$. terangae was also related to the 'E. mexicanus' reference strain LMG 23932 in the analysis of three housekeeping genes ( $g \ln A$, gltA and $\operatorname{rec} A$ ) (not included in Supplementary Fig. S1). The sequence similarities between Cluster $C$ strains and ' $E$. mexicanus' ranged from $92.2 \%$ for $r e c A$, over $93.7 \%$ for $g l t A$, to $95.8 \%$ for $g \ln A$. Between $E$. terangae and 'E. mexicanus' somewhat comparable interspecies sequence similarity values amounted to $96.6 \%$ for recA, $93.5 \%$ for $g l t A$ and $96.2 \%$ for $g \ln A$. This indicated that 'E. mexicanus', E. terangae and the isolates from Cluster $\mathrm{C}$ all represented distinct genomic species.

\section{Sequence analysis of concatenated housekeeping genes}

The $\operatorname{atp} D$ gene was found not to be congruent with the other genes $(P<0.01)$ while all other housekeeping genes showed compatible phylogenetic signals (data not shown). A tree was constructed from the concatenated sequences of the four congruent genes recA, glnA, gltA, and thrC $(P>0.01)$ estimated by the ILD test (Farris et al., 1995). The ILD test values ranged from 0.0120 for $\operatorname{th} r C$ and $r e c A$ to 0.6288 for $\operatorname{thr} C$ and $g \ln A$. In view of the ILD test results, the aligned sequences for $r e c A$, $\operatorname{thr} C$, glt $A$ and $g \ln A$ were concatenated and an alignment of 2704 nucleotides was obtained (comprising 1486 invariable sites, 237 variable but parsimony uninformative sites and 981 parsimony informative sites).

The combined analysis showed a significant cluster (bootstrap value $97 \%$ ), comprising all strains of the genus Ensifer together with clusters A, B and C. The cluster was subdivided into two closely related subclusters. One wellsupported subcluster (bootstrap value 100\%) includes $S$. morelense, the three E. adhaerens genomovars and cluster B. As in most single gene analyses, cluster B formed a significant subclade together with $E$. adhaerens genomovar A. The second major subcluster (bootstrap value 99\%) comprised all other strains of the genus Ensifer and clusters A and C. As found with most single gene trees, Cluster C formed a significant sub branch with $E$. terangae (bootstrap value $100 \%$ ). Cluster A strains ORS $1407^{\mathrm{T}}$ and ORS 1444 also formed a reliable cluster (bootstrap value 100\%), which was well separated from all other genomic species. Since a $t h r C$ sequence could not be obtained for strain ORS 1410 , this strain could not be included in the concatenated housekeeping gene analysis. As indicated, all mentioned clusters were supported by higher bootstrap values in the concatenated tree than in the single gene trees and are therefore more robust. 
Table 2. DNA-DNA hybridization values (\%) between species of the genus Ensifer and strains of cluster B isolated from Lotus arabicus in Senegal

\begin{tabular}{|lrr|}
\hline Strain & $\mathbf{1}$ & $\mathbf{2}$ \\
\hline 1. ORS 529 & 100 & 99 \\
2. ORS 2133 & 99 & 100 \\
E. adhaerens genomovar A LMG 10007 & 74 & 75 \\
E. adhaerens genomovar B R-7457 & 60 & 59 \\
E. adhaerens genomovar C LMG 20216 & 47 & 47 \\
\hline
\end{tabular}

\section{DNA-DNA hybridization}

To determine to which E. adhaerens genomovar Cluster B could be designated, we performed DNA-DNA hybridizations between two strains (ORS 529 and ORS 2133) of this cluster and three E. adhaerens reference strains, representing the three different genomovars (Willems et al., 2003) (Table 2). In agreement with the gene sequence analyses, strains ORS 529 and ORS 2133 displayed high DNA-DNA hybridization values $(99 \%)$, proving that the strains represent the same genomic species. The hybridization values of strains ORS 529 and ORS 2133 with E. adhaerens genomovars $\mathrm{B}$ and $\mathrm{C}$ strains were below $70 \%$, indicating that the two strains from Cluster B are not members of E. adhaerens genomovar B or genomovar C. However, DNA-DNA relatedness values between Cluster $\mathrm{B}$ strains and the E. adhaerens genomovar A reference strain exceeded $70 \%$ which confirmed the assumption drawn from MLSA that Cluster B strains are strains of E. adhaerens genomovar A.

\section{nodA gene sequencing}

The nodA gene was sequenced in strains representing both of the different clusters and host plants of isolation: two cluster C strains (ORS $1400^{\mathrm{T}} /$ Argyrolobium uniflorum and STM 354/Medicago sativa), one cluster B strain ORS 529 (isolated from Lotus arabicus, as were the two other strains of the cluster) and two Cluster A strains (ORS 1444/ Argyrolobium uniflorum and ORS 1410/Lotus creticus). The nodA gene could not be amplified in strain ORS $1407^{\mathrm{T}}$. The analysis of nodA gene sequences by the NJ method (Fig. 2) shows that strains isolated from Argyrolobium uniflorum, Lotus arabicus and Medicago sativa formed a separate cluster. This cluster was grouped with the nodA gene of E. meliloti and the E. medicae branch with high bootstrap support. In this study, the taxonomic position of nodA gene sequences of isolates from Argyrolobium uniflorum is reported for the first time.

\section{Numerical analysis of auxanographic tests}

All strains were tested for use of 99 substrates as the sole carbon source for growth, using API 100 galleries (see Supplementary Table S2 in IJSEM Online). Some discriminative features could be observed.
In contrast to their closest phylogenetic neighbours, E. medicae LMG $19920^{\mathrm{T}}$, E. meliloti LMG $6133^{\mathrm{T}}$ and E. arboris LMG $14919^{\mathrm{T}}$, strains of Cluster A, did not grow on xylitol or DL-glycerate. Results for other substrates were variable between members of this cluster. About 28 substrates were utilized differently by strains ORS 1444, ORS 1410 and ORS $1407^{\mathrm{T}}$ and 13 substrates were only metabolized by strain ORS $1407^{\mathrm{T}}$ (dulcitol, D-lyxose, 1-O-methyl $\alpha$-D-glucopyranoside, 3-Omethyl D-glucopyranose, D-gluconate, L-histidine, succinate, fumarate, ethanolamine, DL- $\beta$-hydroxybutyrate, L-aspartate, $\mathrm{L}$-alanine and propionate).

Cluster B strains used putrescine in contrast to the three genomovars (A, B, C) of E. adhaerens. Seven substrates [(+)-L-sorbose, dulcitol, D-tagatose, citrate, 5-keto-Dgluconate, D-gluconate and glutarate] were not metabolized by members of Cluster B and were used diversely among the three genomovars of E. adhaerens.

Cluster C, which appeared to be close to E. terangae in phylogenetic analyses, differed from this species in the test results for ten substrates. These ten substrates were assimilated by E. terangae LMG $7834^{\mathrm{T}}$ and not by any member of Cluster C. However, malonate was metabolized by all strains of Cluster C and not by E. terangae LMG $7834^{\mathrm{T}}$.

Auxanographic data were analysed numerically (data not shown). Clusters A and C formed two related clusters but were separate from the other species of the genus Ensifer. Strains of Cluster B were included in E. adhaerens as observed in the genotypic analysis, with strain ORS 2154 close to Ensifer adhaerens genomovar B strain R-7457.

\section{DISCUSSION}

In this study, we performed MLSA to characterize nine strains from Tunisia and Senegal which had been isolated from the root nodules of several legumes. Previously, six of them had been partially characterized by ARDRA, SDSPAGE and 16S rRNA gene sequencing (Zakhia et al., 2004). Genes for MLSA were chosen according to previous taxonomic and phylogenetic studies: recA (recombinase A) and atpD (ATP synthase beta subunit) were used in a phylogenetic study of the genera Agrobacterium and Rhizobium (Gaunt et al., 2001); glnA (glutamine synthase) was used by Turner \& Young (2000) and gltA (citrate synthase) was used by Hernandez-Lucas et al. (2004). In a study evaluating the taxonomic potential of ten housekeeping genes, Martens et al. $(2007,2008)$ found these genes and additionally $\operatorname{thr} C$ (threonine synthase) useful for identification and for the inference of phylogenetic relationships of species of the genus Ensifer. Phylogenetic analyses of the five housekeeping genes were compared with the 16S rRNA gene tree using three algorithmic methods (ML, MP and NJ). We completed the characterization with auxanographic tests and $\operatorname{nod} A$ gene sequences for biovar determination.

The nodA gene is a key gene for the establishment of symbiosis; it is present as a single copy and has a size of 


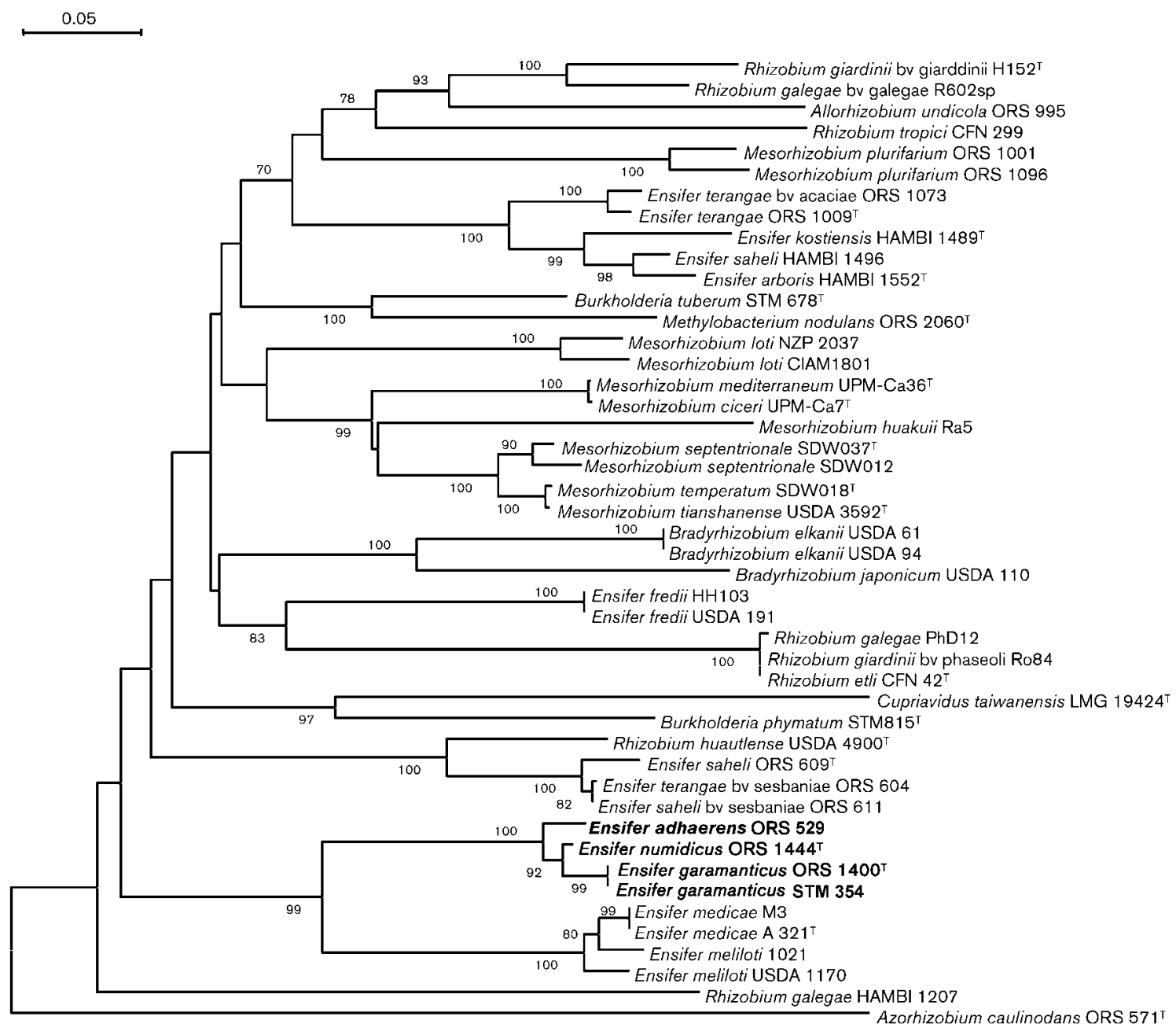

Fig. 2. Neighbour-joining phylogenetic tree of $\operatorname{nod} A$ gene sequences of Tunisian and Senegalese strains. The novel strains are indicated in bold type and bootstrap values $>60 \%$ (using 1000 replicates) are indicated at branching points. Bar, 0.05 estimated substitutions.

590-660 bp (Moulin et al., 2004). Except for some photosynthetic species of the genus Bradyrhizobia (Giraud et al., 2007), all bacteria described thus far as being capable of establishing a symbiosis with legumes harbour nodulation (nod) and nitrogen fixation ( $n i f$, fix) genes. This opens up the possibility of screening for these genes as an alternative to nodulation tests. The encoded $\alpha \beta$-unsaturated Nod factor protein is a key enzyme for Nod factor synthesis, transferring an acyl chain on a chitin oligomer, resulting in a biologically active NodA molecule. The sequence of the nodA gene provides information regarding the symbiotic characteristics of the rhizobium and may be predictive for the type of Nod factor produced and for host specificity (Lortet et al., 1996; Debellé et al., 2001). As the nodA gene is frequently plasmidborne and has a propensity towards lateral gene transfer, the sequence of the gene is usually indicative of the biovar rather than the species affiliation (Haukka et al., 1998).

All phylogenies based on the three algorithmic methods unambiguously placed the nine root nodule strains within the Class Alphaproteobacteria, in the Ensifer clade. The nine strains were subdivided into three monophyletic clusters with a high intra-species sequence similarity of $100 \%$ for all gene sequence analyses.

Cluster A formed a separate cluster with variable positions relative to the reference species of the genus Ensifer in the phylogenies based on the 16S rRNA gene and all of the housekeeping genes. In the concatenated gene sequence analysis, Cluster A formed a single, separate cluster which was clearly distinguished from all of the other clusters. The sequence similarities between Cluster A strains and strains of related reference species supported this segregation. The gene sequence similarity values between members of Cluster $\mathrm{A}$ and the other genotypic clusters ranged between 82 and $94.3 \%$ in the different gene analyses (see Supplementary Fig. S1 in IJSEM Online). 'Sinorhizobium chiapanecum', related to $E$. terangae, was reported during the process of revision of the present work (Rincón-Rosales et al., 2009). The available recA and 16S rRNA gene sequences of this species were 
retrieved and it was observed that both genes place 'S. chiapanecum', E. terangae and 'E. mexicanus' in a cluster [96.3-96.9\% (recA) and 99.3-99.7\% (16S RNA gene) internal similarity values], away from Cluster A, with interspecies similarity values ranging from $92.2-92.6 \%$ (recA) and 98.4-98.9\% (16S RNA gene).

These values illustrate a clear gap in sequence similarity levels within Cluster A strains and between Cluster A and other reference strains, corresponding to the inter- and intra-species sequence similarity value gap observed by Martens et al. $(2007,2008)$ in their comparison of MLSA and DNA-DNA hybridization data. This indicates that Cluster A strains are well distinguished from the reference species of the genus Ensifer and therefore represent a new genomic species.

The auxanographic tests also confirmed that members of Cluster A represented a novel species of the genus Ensifer. The nodA gene sequence of a representative strain of Cluster A, strain ORS 1444, was examined in order to obtain some information regarding the Nod factor of Argyrolobium uniflorum microsymbionts. The results showed that this strain grouped in a separate cluster close to the E. meliloti/E. medicae nodA group. In view of our phenotypic and genotypic results and those obtained in previous studies (Zakhia et al., 2004), we propose a novel species of the genus Ensifer for the Cluster A strains with the name Ensifer numidicus sp. nov. Strain ORS $1407^{\mathrm{T}}$ is designated as the type strain.

In a parallel and independent work, Mahdhi et al. (2008) described root nodule isolates from Argyrolobium uniflorum in the same region of Tunisia. Among the most effective strains (potential candidates for inoculant production), 13 formed a homogeneous and separate group on the Ensifer branch when investigated by $16 \mathrm{~S}$ rRNA gene PCR-RFLP. Three representative strains of this group were sequenced, and they shared identical nucleotide sequences with strain ORS 1444. This group may thus be considered as members of E. numidicus sp. nov.

Cluster B formed a monophyletic group in all phylogenies and grouped separately with E. adhaerens genomovar A in the majority of the gene phylogenies. In the 16S rRNA gene tree, Cluster B strains were grouped together with the genomovars of E. adhaerens and S. morelense. In the single and concatenated housekeeping gene analyses, Cluster B grouped with $E$. adhaerens genomovar A, supported by high bootstrap values. The analysis of the gene sequence similarities placed Cluster B in the gap between intra- and interspecies sequence similarities values, confirming that the members of Cluster B belong to the species E. adhaerens but with an uncertain genomovar position. Following the recommendation of Willems et al. (2003) for genomovar discrimination, DNA-DNA hybridization experiments were conducted. The results confirmed that members of Cluster B were different from genomovars B and C and belonged to E. adhaerens genomovar A. Phenotypic and genotypic analyses clearly indicated that Cluster B grouped with E. adhaerens genomovar A. All strains from Cluster B nodulate the plant from which they were isolated, Lotus arabicus. This is in contrast to all recognized members of E. adhaerens (Casida, 1982; Willems et al., 2003), even though Rogel et al. (2001) demonstrated that they may acquire nodulation capacity upon the introduction of symbiotic plasmids.

Cluster C formed a separate monophyletic group in all phylogenies, essentially in the E. terangael'E. mexicanus' clade. A similar grouping was obtained using the four congruent genes $(g \ln A, g l t A, \operatorname{th} r C$ and $r e c A)$ in individual gene analyses and in the concatenated gene trees. Sequence similarity values indicated a clear gap between the similarity levels within Cluster $\mathrm{C}$ strains and between strains of Cluster $\mathrm{C}$ and other reference strains. Values between Cluster $\mathrm{C}$ strains and the reference strains were comparable with those at the interspecies level found by Martens et al. (2008) in their study comparing MLSA and DNA-DNA hybridization data. This indicated that Cluster $\mathrm{C}$ was distinct and formed a separate genospecies. In addition, the numerical analysis of auxanographic results confirmed that Cluster $\mathrm{C}$ was separate from all species of the genus Ensifer. In contrast to their closest phylogenetic neighbour E. terangae LMG $7834^{\mathrm{T}}$, Cluster C strains were able to utilize malonate, but not $p$-hydroxybenzoate. Two representative strains of Cluster C, ORS $1400^{\mathrm{T}}$ and STM 354, isolated from two different legumes, exhibited nodA gene sequences which grouped together (bootstrap value $99 \%$ ) with those from Cluster A and B, in the E. meliloti and E. medicae branch. The combination of the results obtained previously by Zakhia et al. (2004) and in this study by MLSA and additional 16S rRNA and nodA gene sequence analyses and auxanographic tests indicate that Cluster $C$ represents a novel genospecies in the E. terangae/ 'E. mexicanus' clade, for which we propose the name Ensifer garamanticus sp. nov., with strain ORS $1400^{\mathrm{T}}$ as the type strain.

Additional DNA-DNA hybridization experiments to establish the separate species status of clusters $A$ and $C$ were not performed due to the clarity of the MLSA evidence. In this study, the highest gene sequence similarity level with other species of the genus Ensifer obtained for Cluster A was $94.3 \%$ $($ atpD). For Cluster $\mathrm{C}$, this value was $96.4 \%$ (gltA). In view of the finding that strains of Cluster $\mathrm{B}$, with housekeeping gene sequence similarity levels of $96.4-98.4 \%$ with $E$. adhaerens genomovars $\mathrm{B}$ and $\mathrm{C}$, produced DNA-DNA relatedness levels below the species threshold (Table 2, 47-60\%), even lower DNA-DNA binding between strains that have lower gene sequence similarity levels in housekeeping genes would be expected. This information is also in line with a previous elaborate comparison of housekeeping gene sequences and DNA-DNA hybridization data (Martens et al., 2008) where it was shown that MLSA of selected housekeeping genes can accurately predict relationships between closely related organisms. It is concluded Clusters $\mathrm{A}$ and $\mathrm{C}$ represent two novel species of the genus Ensifer species, for which the names of Ensifer numidicus and Ensifer garamanticus are proposed, respectively. 


\section{Description of Ensifer numidicus sp. nov.}

Ensifer numidicus (nu.mi'di.cus. L. masc. adj. numidicus pertaining to the country of Numidia, Numidian, the Roman denomination of the region in North Africa from which the majority of the organisms were isolated).

Short, aerobic, Gram-negative, non-spore-forming rods. Strains grow on yeast-mannitol medium, on which they form white slightly mucous colonies after 3 days at $28{ }^{\circ} \mathrm{C}$. At the molecular level, this species can be differentiated by phylogenetic analysis based on several housekeeping genes (recA, glnA, gltA, thrC and atpD) and 16S rRNA gene sequencing. Its phylogenetic neighbours are E. medicae, E. meliloti and E. arboris. Detailed phenotypic features for strains of the species are given in Supplementary Table S2. Can be distinguished from E. medicae, E. meliloti and E. arboris by the differential use of a combination of growth substrates. Does not grow on xylitol or DL-glycerate. Results for other substrates were variable between members of this cluster (Cluster A). In the API 100 gallery, about 28 substrates are used differently by strains ORS 1444, ORS 1410 and ORS $1407^{\mathrm{T}}$. The type strain metabolizes only 13 substrates: dulcitol, D-lyxose, 1-O-methyl $\alpha$-D-glucopyranoside, 3-O-methyl-D-glucopyranose, D-gluconate, L-histidine, succinate, fumarate, ethanolamine, DL- $\beta$-hydroxybutyrate, L-aspartate, L-alanine and propionate. Strains cannot be identified by biochemical and physiological characters alone. Strains are able to nodulate Argyrolobium uniflorum (ORS 1444 and ORS $1407^{\mathrm{T}}$ ) and Lotus creticus (ORS 1410). The sequence of the nodulation gene nodA differs from those of other species of the genus Ensifer but is most closely related to those of the E. meliloti and E. medicae clade.

The type strain is ORS $1407^{\mathrm{T}}\left(=\mathrm{LMG} 24690^{\mathrm{T}}=\mathrm{CIP} 109850^{\mathrm{T}}\right)$. The DNA $\mathrm{G}+\mathrm{C}$ content of the type strain is $62.8 \mathrm{~mol} \%$ (HPLC).

A group of 13 Sinorhizobium sp. strains reported by Mahdhi et al. (2008), AB1, AB3, AB5, AB6, AB10, AM1, AM2, AM3, AS1, AS2, AS3, AS4, AS5, may be considered as belonging to Ensifer numidicus and are included as members of this species. These strains were isolated independently from Argyrolobium uniflorum in South Tunisia. The strains form a homogeneous group by PCR-RFLP of the 16S rRNA gene. Three representative strains of this group STM 4034 (=AB1), STM 4036 (=AB3), STM 4039 (=AS1), share identical $16 \mathrm{~S}$ rRNA gene sequences with strains of E. numidicus as isolated in this study. The three latter strains form the most effective symbiosis with Argyrolobium uniflorum and strain STM 4036 is the most efficient. The additional strains tolerate $\mathrm{pH}$ values of $6-9,1-2 \%(\mathrm{w} / \mathrm{v})$ $\mathrm{NaCl}$ and grow at $40{ }^{\circ} \mathrm{C}$, but not at $45{ }^{\circ} \mathrm{C}$. They are sensitive to $\left(\mu \mathrm{g} \mathrm{ml}^{-1}\right)$ ampicillin (100) and streptomycin (100), but resistant to kanamycin (100) and nalidixic acid (100).

\section{Description of Ensifer garamanticus sp. nov.}

Ensifer garamanticus (ga.ra.man'ti.cus. L. masc. adj. garamanticus, pertaining to Garamante, Garamantian, the country of Garamantes, from which the strains were isolated).

Short, aerobic, Gram-negative, non-spore-forming rods. The strains form white and slightly mucous colonies on YMA after $48-72 \mathrm{~h}$ incubation at $28{ }^{\circ} \mathrm{C}$.

Strains efficiently nodulate Argyrolobium uniflorum (ORS $1400^{\mathrm{T}}$, ORS 1401) and Medicago sativa (STM 354). Can be distinguished from other species by phylogenetic analysis based on several housekeeping ( $r e c A, g \ln A, g l t A$, thrC and atpD) genes and 16S rRNA gene sequencing. Malonate is used by all strains for growth, but is not used by the closest phylogenetic neighbour E. terangae. Detailed phenotypic features for all strains are given in Supplementary Table S2. In the API 100 galleries, ten substrates are used for growth by E. terangae LMG $7834^{\mathrm{T}}$ but not by any member of Ensifer garamanticus (Cluster C). Malonate is metabolized by all strains and not by E. terangae LMG $7834^{\mathrm{T}}$.

The type strain is ORS $1400^{\mathrm{T}}\left(=\mathrm{LMG} 24692^{\mathrm{T}}=\mathrm{CIP}\right.$ $\left.109916^{\mathrm{T}}\right)$. The DNA $\mathrm{G}+\mathrm{C}$ content of the type strain is $62.4 \%$ (HPLC).

The group formed by Sinorhizobium sp. strains STM 4015, STM 4016, STM 4027, STM 4031, STM 4032, isolated from Genista saharae in South Tunisia by Mahdhi et al. (2007), share identical 16S rRNA gene sequence with the type strain of E. garamanticus. They may be thus be considered as members of this species. These strains generally tolerate high temperatures $\left(40{ }^{\circ} \mathrm{C}\right)$, high $\mathrm{pH}$ values (7-12) and high $\mathrm{NaCl}$ concentrations $(1-4 \%$, w/v) for growth. They nodulate their plant of isolation, so that Genista saharae may also be considered as a potential host plant of Ensifer garamanticus.

\section{ACKNOWLEDGEMENTS}

The authors are grateful to F. Boukhatem, B. Dreyfus, A. Galiana, L. Moulin, G. Béna, B. Hamed Bey, H. Ameziane and L. Bouchentouf for helpful discussions. C. M., F. Z., A. B. and A.S. are indebted to the Département Soutien-Formation (DSF) of the Institut de Recherche pour le Développement (IRD), France, for a $\mathrm{PhD}$ fellowship and ESCD grants and M. Mosbah for the AUF grant. A. W is grateful to the Fund for Scientific Research - Flanders for a postdoctoral fellowship. This work was supported by the Commission of the European Communities RT-program contract BACDIVERS QLRT2001-02097.

\section{REFERENCES}

Baele, M., Baele, P., Vaneechoutte, M., Storms, V., Butaye, P., Devriese, L. A., Verschraegen, G., Gillis, M. \& Haesebrouck, F. (2000). Application of tRNA intergenic spacer PCR for identification of Enterococcus species. J Clin Microbiol 38, 4201-4207.

Bailly, X., Olivieri, I., de Mita, S., Cleyet-Marel, J.-C. \& Béna, G. (2006). Recombination and selection shape the molecular diversity pattern of nitrogen-fixing Sinorhizobium sp. associated to Medicago. Mol Ecol 15, 2719-2734. 
Balkwill, D. L. (2005). Genus VI. Ensifer Casida 1982, $343^{\mathrm{VP}}$. In Bergey's Manual of Systematic Bacteriology, 2nd edn, vol. 2, part C, pp. 354-358. Edited by D. J. Brenner, N. R. Krieg J. T. Staley \& G. M. Garrity. New York: Springer.

Bertrand, H. (1997). Stimulation de l'absorption minérale et de la croissance du Colza inoculé avec des bactéries isolées de son rhizoplan. PhD thesis, Université Claude Bernard-Lyon I (in French).

Casida, L. E., Jr (1982). Ensifer adhaerens gen. nov., sp. nov. a bacterial predator of bacteria in soil. Int J Syst Bacteriol 32, 339-345.

Coenye, T., Gevers, D., Van de Peer, Y., Vandamme, P. \& Swings, J. (2005). Towards a prokaryotic genomic taxonomy. FEMS Microbiol Rev 29, 147-167.

de Lajudie, P., Willems, A., Pot, B., Dewettinck, D., Maestrojuan, G., Neyra, M., Collins, M. D., Dreyfus, B. L., Kersters, K. \& Gillis, M. (1994). Polyphasic taxonomy of rhizobia: emendation of the genus Sinorhizobium and description of Sinorhizobium meliloti comb. nov., Sinorhizobium saheli sp. nov. and Sinorhizobium teranga sp. nov. Int J Syst Bacteriol 44, 715-733.

Debellé, F., Moulin, L., Mangin, B., Dénarié, J. \& Boivin, C. (2001). nod genes and Nod signals and the evolution of the Rhizobium legume symbiosis. Acta Biochim Pol 48, 359-365.

Eardly, B. D., Nour, S. M., van Berkum, P. \& Selander, R. K. (2005). Rhizobial 16S rRNA and dnaK genes: mosaicism and the uncertain phylogenetic placement of Rhizobium galegae. Appl Environ Microbiol 71, 1328-1335.

Ezaki, T., Hashimoto, Y. \& Yabuuchi, E. (1989). Fluorometric deoxyribonucleic acid-deoxyribonucleic acid hybridization in microdilution wells as an alternative to membrane filter hybridization in which radioisotopes are used to determine genetic relatedness among bacterial strains. Int J Syst Bacteriol 39, 224-229.

Farris, J. S., Källersjö, M., Kluge, A. G. \& Bult, C. (1995). Constructing a significance test for incongruence. Syst Biol 44, 570-572.

Ferchichi, A. (1996). La lutte contre l'ensablement et pour la stabilisation des dunes: essai de la fixation biologique des dunes en Tunisie presaharienne. Recherche sur la désertification dans la Jeffara. Rev Tunis Geogr 12, 49-102 (in French).

Gaunt, M. W., Turner, S. L., Rigottier-Gois, L., Lloyd-Macgilp, S. A. \& Young, J. P. W. (2001). Phylogenies of atpD and recA support the small subunit rRNA-based classification of rhizobia. Int J Syst Evol Microbiol 51, 2037-2048.

Gevers, D., Cohan, F. M., Lawrence, J. G., Spratt, B. G., Coenye, T., Feil, E. J., Stackebrandt, E., Van de Peer, Y., Vandamme, P. \& other authors (2005). Opinion: re-evaluating prokaryotic species. Nat Rev Microbiol 3, 733-739.

Giraud, E., Moulin, L., Vallenet, D. \& other authors (2007). Legumes symbioses: absence of Nod genes in photosynthetic bradyrhizobia. Science 316, 1307-1312.

Goris, J., Suzuki, K., De Vos, P., Nakase, T. \& Kersters, K. (1998). Evaluation of a microplate DNA-DNA hybridization method compared with the initial renaturation method. Can J Microbiol 44, $1148-1153$.

Haukka, K., Lindström, K. \& Young, J. P. W. (1998). Three phylogenetic groups of nodA and nifH genes in Sinorhizobium and Mesorhizobium isolates from leguminous trees growing in Africa and Latin America. Appl Environ Microbiol 64, 419-426.

Hernandez-Lucas, I., Rogel-Hernandez, M. A., Segovia, L., RojasJiménez, K. \& Martinez-Romero, E. (2004). Phylogenetic relationships of rhizobia based on citrate synthase gene sequences. Syst Appl Microbiol 27, 703-706.

Judicial Commission of the International Committee on Systematics of Prokaryotes (2008). The genus name Sinorhizobium Chen et al. 1988 is a later synonym of Ensifer Casida 1982 and is not conserved over the latter genus name, and the species name 'Sinorhizobium adhaerens' is not validly published. Opinion 84. Int J Syst Evol Microbiol 58, 1973.

Kersters, K. \& De Ley, J. (1984). Genus III. Agrobacterium Conn 1942. In Bergey's Manual of Systematic Bacteriology, vol. 1 pp. 244-254. Edited by N. R. Krieg \& J. G. Holt. Baltimore: The Williams \& Wilkins Co.

Kimura, M. (1980). A simple method for estimating evolutionary rates of base substitutions through comparative studies of nucleotide sequences. J Mol Evol 16, 111-120.

Lloret, L., Ormeño-Orrillo, E., Rincón, R., Martínez-Romero, J., Rogel-Hernández, M. A. \& Martínez-Romero, E. (2007). Ensifer mexicanus sp. nov. a new species nodulating Acacia angustissima (Mill.) Kuntze in Mexico. Syst Appl Microbiol 30, 280-290.

Lortet, G., Mear, N., Lorquin, J., Dreyfus, B., de Lajudie, P., Rosenberg, C. \& Boivin, C. (1996). Nod factor thin-layer chromatography profiling as a tool to characterize symbiotic specificity of rhizobial strains: application to Sinorhizobium saheli, S. teranga and Rhizobium sp. strains isolated from Acacia and Sesbania. Mol Plant Microbe Interact 9, 736-747.

Mahdhi, M., Nzoué, A., Gueye, F., Merabet, C., de Lajudie, P. \& Mars, M. (2007). Phenotypic and genotypic diversity of Genista saharae microsymbionts from the infra-arid region of Tunisia. Lett Appl Microbiol 45, 604-609.

Mahdhi, M., de Lajudie, P. \& Mars, M. (2008). Phylogenetic and symbiotic characterization of rhizobial bacteria nodulating Argyrolobium uniflorum in Tunisian arid soils. Can J Microbiol 54, 209-217.

Mantelin, S., Fischer-Le Saux, M., Zakhia, F., Béna, G., Bonneau, S., Jeder, H., de Lajudie, P. \& Cleyet-Marel, J. C. (2006). Emended description of the genus Phyllobacterium and description of four novel species associated with plant roots Phyllobacterium bourgognense sp. nov., Phyllobacterium ifriqiyense sp. nov., Phyllobacterium leguminum sp. nov. and Phyllobacterium brassicacearum sp. nov. Int J Syst Evol Microbiol 56, 827-839.

Marmur, J. (1961). A procedure for the isolation of deoxyribonucleic acid from microorganisms. J Mol Biol 3, 208-218.

Martens, M., Delaere, M., Coopman, R., De Vos, P., Gillis, M. \& Willems, A. (2007). Multilocus sequence analysis of Ensifer and related taxa. Int J Syst Evol Microbiol 57, 489-503.

Martens, M., Dawyndt, P., Coopman, R., Gillis, M., De Vos, P. \& Willems, A. (2008). Advantages of multilocus sequence analysis for taxonomic studies: a case study using 10 housekeeping genes in the genus Ensifer (including former Sinorhizobium). Int J Syst Evol Microbiol 58, 200-214.

Moulin, L., Béna, G., Boivin-Masson, C. \& Stepkowski, T. (2004). Phylogenetic analyses of symbiotic nodulation genes support vertical and lateral gene co-transfer within the Bradyrhizobium genus. Mol Phylogenet Evol 30, 720-732.

Naser, S. M., Thompson, F. L., Hoste, B., Gevers, D., Dawyndt, P., Vancanneyt, M. \& Swings, J. (2005). Application of multilocus sequence analysis (MLSA) for rapid identification of Enterococcus species based on rpoA and pheS genes. Microbiology 151, 2141-2150.

Posada, D. \& Buckley, T. R. (2004). Model selection and model averaging in phylogenetics: advantages of the Akaike Information Criterion and Bayesian approaches over likelihood ratio tests. Syst Biol 53, 793-808.

Posada, D. \& Crandall, K. A. (1998). MODELTEST: testing the model of DNA substitution. Bioinformatics 14, 817-818.

Rincón-Rosales, R., Lloret, L., Ponce, E. \& Martínez-Romero, E. (2009). Rhizobia with different symbiotic efficiencies nodulate Acaciella angustissima in Mexico, including Sinorhizobium chiapane- 
cum sp. nov. which has common symbiotic genes with Sinorhizobium mexicanum. FEMS Microbiol Ecol 67, 103-117.

Rogel, M. A., Hernandez-Lucas, I., Kuykendall, L. D., Balkwill, D. L. \& Martínez-Romero, E. (2001). Nitrogen-fixing nodules with Ensifer adhaerens harbouring Rhizobium tropici symbiotic plasmids. Appl Environ Microbiol 67, 3264-3268.

Saitou, N. \& Nei, M. (1987). The neighbour joining method: a new method for reconstructing phylogenetic trees. Mol Biol Evol 4, 406425.

Schouls, L. M., Schot, C. S. \& Jacobs, J. A. (2003). Horizontal transfer of segments of the 16S rRNA genes between species of the Streptococcus anginosus group. J Bacteriol 185, 7241-7246.

Soler, L., Yáñez, M. A., Chacon, M. R., Aguilera-Arreola, M. G., Catalán, V., Figueras, M. J. \& Martínez-Murcia, A. J. (2004). Phylogenetic analysis of the genus Aeromonas based on two housekeeping genes. Int J Syst Evol Microbiol 54, 1511-1519.

Stackebrandt, E. (2003). The richness of prokaryotic diversity: there must be a species somewhere. Food Technol Biotechnol 41, 17-22.

Stackebrandt, E., Frederiksen, W., Garrity, G. M., Grimont, P. A., Kämpfer, P., Maiden, M. C., Nesme, X., Rosselló-Mora, R., Swings, J. $\&$ other authors (2002). Report of the ad hoc committee for the reevaluation of the species definition in bacteriology. Int J Syst Evol Microbiol 52, 1043-1047.

Stepkowski, T., Czaplinska, M., Miedzinska, K. \& Moulin, L. (2003). The variable part of the $d n a K$ gene as an alternative marker for phylogenetic studies of rhizobia and related alpha Proteobacteria. Syst Appl Microbiol 26, 483-494.

Swofford, D. L. (2002). PAUP*: Phylogenetic analysis using parsimony (and other methods), version 4. Sunderland, MA: Sinauer Associates.

Thompson, J. D., Gibson, T. J., Plewniak, F., Jeanmougin, F. \& Higgins, D. G. (1997). The CLUSTAL_X windows interface: flexible strategies for multiple sequence alignment aided by quality analysis tools. Nucleic Acids Res 25, 4876-4882.

Toledo, I., Lloret, L. \& Martínez-Romero, E. (2003). Sinorhizobium americanum sp. nov., a new Sinorhizobium species nodulating native Acacia spp. in Mexico. Syst Appl Microbiol 26, 54-64.

Turner, S. L. \& Young, J. P. W. (2000). The glutamine synthetases of rhizobia: phylogenetics and evolutionary implications. Mol Biol Evol 17, 309-319.

Ueda, K., Seki, T., Kudo, T., Yoshida, T. \& Kataoka, M. (1999). Two distinct mechanisms cause heterogeneity of $16 \mathrm{~S}$ rRNA. J Bacteriol 181, 78-82.

van Berkum, P., Terefework, Z., Paulin, L., Suomalainen, S., Lindström, K. \& Eardly, B. D. (2003). Discordant phylogenies within the rrn loci of rhizobia. J Bacteriol 185, 2988-2998.

Vandamme, P., Pot, B., Gillis, M., De Vos, P., Kersters, K. \& Swings, J. (1996). Polyphasic taxonomy, a consensus approach to bacterial systematics. Microbiol Rev 60, 407-438.

Vinuesa, P., Silva, C., Lorite, M. J., Izaguirre-Mayoral, M. L., Bedmar, E. \& Martinez-Romero, E. (2005a). Molecular systematics of rhizobia based on maximum likelihood and Bayesian phylogenies inferred from $r r s$, atpD, recA and nifH sequences, and their use in the classification of Sesbania microsymbionts from Venezuelan wetlands. Syst Appl Microbiol 28, 702-716.

Vinuesa, P., Silva, C., Werner, D. \& Martinez-Romero, E. (2005b). Population genetics and phylogenetic inference in bacterial molecular systematics: the roles of migration and recombination in Bradyrhizobium species cohesion and delineation. Mol Phylogenet Evol 34, 29-54.

Vinuesa, P., León-Barrios, M., Silva, C., Willems, A., Jarabo-Lorenzo, A., Pérez-Galdona, R. \& Martínez-Romero, E. (2005c). Bradyrhizobium canariense sp. nov., an acid-tolerant endosymbiont that nodulates endemic genistoid legumes (Papilionoideae: Genisteae) growing in the Canary Islands, along with Bradyrhizobium japonicum bv. genistearum, Bradyrhizobium genospecies alpha and Bradyrhizobium genospecies beta. Int J Syst Evol Microbiol 55, 569-575.

Wang, E. T., Tan, Z. Y., Willems, A., Fernandez-Lopez, M., ReinholdHurek, B. \& Martinez-Romero, E. (2002). Sinorhizobium morelense sp. nov., a Leucaena leucocephala-associated bacterium that is highly resistant to multiple antibiotics. Int J Syst Evol Microbiol 52, 1687-1693.

Wei, G. H., Wang, E. T., Tan, Z. Y., Zhu, M. E. \& Chen, W. X. (2002). Rhizobium indigoferae sp. nov. and Sinorhizobium kummerowiae sp. nov., respectively isolated from Indigofera spp; and Kummerowia stipulacea. Int J Syst Evol Microbiol 52, 2231-2239.

Wertz, J. E., Goldstone, C., Gordon, D. M. \& Riley, M. A. (2003). A molecular phylogeny of enteric bacteria and implications for a bacterial species concept. J Evol Biol 16, 1236-1248.

Willems, A., Doignon-Bourcier, F., Goris, J., Coopman, R., de Lajudie, P., De Vos, P. \& Gillis, M. (2001). DNA-DNA hybridization study of Bradyrhizobium strains. Int J Syst Evol Microbiol 51, 13151322.

Willems, A., Fernandez-Lopez, M., Munoz-Adelantado, E., Goris, J., De Vos, P., Martínez-Romero, E., Toro, N. \& Gillis, M. (2003). Description of new Ensifer strains from nodules and proposal to transfer Ensifer adhaerens Casida 1982 to Sinorhizobium as Sinorhizobium adhaerens comb. nov. Request for an Opinion. Int J Syst Evol Microbiol 53, 12071217.

Young, J. M. (2003). The genus name Ensifer Casida 1982 takes priority over Sinorhizobium Chen et al. 1988, and Sinorhizobium morelense Wang et al. 2002 is a later synonym of Ensifer Casida 1982. Is the combination Sinorhizobium adhaerens (Casida 1982) Willems et al., 2003 legitimate? Request for an Opinion. Int J Syst Evol Microbiol 53, 2107-2110.

Zakhia, F. (2004). Diversité des bactéries hôtes de légumineuses méditerranéennes en Tunisie et au Liban. $\mathrm{PhD}$ thesis, Université de Montpellier, France (in French).

Zakhia, F., Jeder, H., Domergue, O., Willems, A., Cleyet-Marel, J.-C., Gillis, M., Dreyfus, B. \& de Lajudie, P. (2004). Characterisation of wild legume nodulating bacteria (LNB) in the infa-arid zone of Tunisia. Syst Appl Microbiol 27, 380-395.

Zakhia, F., Jeder, H., Willems, A., Dreyfus, B. \& de Lajudie, P. (2006). Diverse bacteria associated with root nodules of spontaneous legumes in Tunisia and first report for nifH-like gene within the genera Microbacterium and Starkeya. Microb Ecol 51, 375-393.

Zeigler, D. R. (2003). Gene sequences useful for predicting relatedness of whole genomes in bacteria. Int J Syst Evol Microbiol 53, 1893-1900. 